\title{
Comparison of immunohistochemistry and virus cultivation for detection of viral haemorrhagic septicaemia virus in experimentally infected rainbow trout Oncorhynchus mykiss
}

\author{
Øystein Evensen ${ }^{1}$, Willy Meier ${ }^{2}$, Thomas Wahli ${ }^{2}$, Niels J. Olesen ${ }^{3}$, \\ Poul E. Vestergård Jørgensen ${ }^{3}$, Tore Håstein ${ }^{4}$ \\ ${ }^{1}$ Central Veterinary Laboratory, Department of pathology, PO Box 8156 Dep., N-0033 Oslo, Norway \\ ${ }^{2}$ University of Berne, Fish Disease Laboratory, Längass-strasse 122, CH-3012 Berne, Switzerland \\ ${ }^{3}$ National Veterinary Laboratory, Hangøvej 2, DK-8200 Århus N, Denmark \\ ${ }^{4}$ Central Veterinary Laboratory, Department of fish health, PO Box 8156 Dep., N-0033 Osla, Norway
}

\begin{abstract}
Immunohistochemistry and virus isolation were compared for their ability to detect viral haemorrhagic septicaemia virus (VHS) in experimentally infected rainbow trout Oncorhynchus mykiss. The fish were divided into 3 groups (I to III), and infected, respectively, by bath challenge with $10^{2}$, $10^{3.7}$, and $10^{5} \mathrm{TCID}_{50} \mathrm{ml}^{-1}$ water of a VHS virus strain serologically similar to reference strain $\mathrm{F} 1$ The cumulative mortality in Groups I to III was 44,64, and $96 \%$, respectively, at $14 \mathrm{~d}$ post infection (p.i.). Statistical comparison of the results from all groups showed that virus isolation was significantly more sensitive than immunohistochemistry $(p<0.05)$. The same result was obtained by separate comparison of Groups I and II, but there was no significant difference between the 2 methods for Group III $\left(10^{5} \mathrm{TCID}_{50}\right)$. Immunohistochemically, virus antigens were detected early ( 2 to $\left.4 \mathrm{~d}\right)$ in endothelial cells linıng venules and sinusoids and in the haematopoietic cells in the head kidney, as well as in interstitial macrophages and melanomacrophages; they were detected subsequently in hepatocytes ( $4 \mathrm{~d}$ p.i.) and exocrine pancreatic cells ( $6 \mathrm{~d}$ p.i.). Presence of virus was accompanied by cell degeneration and necrosis from $4 \mathrm{~d}$ p.i. in all positive organs. These findings show that virus cultivation is the most sensitive method for detection of virus, although immunohistochemistry may represent an adjunct to diagnosis of acute VHS virus infections. The main advantage of immunohistochemistry is the possibility of simultaneous demonstration of virus and morphological changes, making it a valuable tool for pathogenesis studies.
\end{abstract}

KEY WORDS: VHS virus - Virus cultivation - Immunohistochemistry - Rainbow trout - Oncorhynchus mykiss

\section{INTRODUCTION}

Viral haemorrhagic septicaemia (VHS) virus is the causative agent of VHS in rainbow trout Oncorhynchus mykiss, and is one of the most severe pathogens encountered in European trout farms (Jensen 1965, Wolf 1988). The virus is also pathogenic for other fish species, and experimental infection causes mortality in Atlantic salmon Salmo salar L. (de Kinkelin \& Castric 1982). Several species of trout (Rasmussen 1965, Ahne et al. 1976, de Kinkelin \& Le Berre 1977), grayling Thymallus thymallus (Wizigmann et al. 1980), pike Esox Iucius L. (Meier \& Jørgensen 1979), white fishes Coregonus spp. (Ahne \& Thomsen 1985, Meier et al. 1986), turbot fry Scophthalmus maximus and sea bass Dicentrarchus labrax (Castric \& de Kinkelin 1984) are susceptible. VHS virus has also been isolated from Atlantic cod Gadus morhua (Jensen et al. 1979, Jørgensen \& Olesen 1987), and in addition, serologically indistinguishable but genetically different viruses 
have been obtained from chinook salmon $O$. tshawytscha, coho salmon $O$. kisutch, Pacific cod Gadus macrocephalus (Oshima et al. 1993) and herring Clupea harengus pallasi (Dr J R. Winton, National Fisheries Research Laboratory, Seattle, WA, USA, pers. comm.).

Although a presumptive diagnosis of VHS may be based on clinical signs and pathological changes in internal organs, confirmation of the diagnosis of VHS requires virus isolation followed by serological identification (Jørgensen 1974a). Many serological tests have been described, while a limited number of studies have addressed the in situ detection of VHS virus, with (Jørgensen \& Meyling 1972, Kruse \& Neukirch 1989, Ortega et al. 1992) or without (Wizigmann \& Hoffmann 1982) parallel cultivation. Most of the studies referred to concluded that immunohistochemical techniques reveal fewer positive samples than virus cultivation. For diagnostic purposes, immunoenzyme techniques have also been used for detection of VHS virus in cell culture (Faisal \& Ahne 1980, Sanz \& Coll 1992), but there are few reports (Kruse \& Neukirch. 1989) on the use of this method for in situ demonstration of virus. The evaluation of new methods for supplementary use in the diagnosis of VHS is dependent on careful comparative studies on their sensitivity. Sensitivity in immunohistochemical terms is expressed as the lowest amount or concentration of antigen detected (Petrusz et al. 1980). This parameter is, however, difficult to evaluate in the context of virus isolation. Therefore, to overcome this difficulty, an appropriate approach would seem to be to carry out studies including virus isolation and in situ detection of virus for direct comparison of the 2 methods.

Present knowledge of the pathogenesis of VHS is limited (Wolf 1988), but the kidney and liver are considered to be the prime target organs. Although an intense replication of virus seems to take place in interstitial cells in the kidney, the precise phenotype of these target cells is poorly characterized (de Kinkelin et al. 1979). Endothelial cells have also been described as one of the prime target cell populations in the head kidney (Meier \& Pfister 1981), and in both the liver and head kidney (Wizigmann \& Hoffmann 1982). Immunohistochemistry is suitable for pathogenicity studies, especially immunoenzyme-based immunohistochemical techniques which allow simultaneous evaluation of pathological changes and in situ detection of virus. However, any study aimed at characterizing the target cell type for a given infectious agent in fish is hampered by the fact that there are few phenotype-specific immune sera or monoclonal antibodies available that react in fish tissues.

The purposes of the present investigation were (1) to develop an immunoenzymatic method for in situ identi- fication of VHS virus in formalin-fixed, paraffin-embedded tissue specimens and compare the results to those obtained using virus isolation, and (2) to study the sequential spread and occurrence of the virus in different organs or cells during experimental infection in rainbow trout, using immunohistochemical techniques

\section{MATERIALS AND METHODS}

Fish. The 400 experimental fish, full siblings of rainbow trout of $15 \mathrm{~cm}$ length, were obtained from the facilities of the fish disease laboratory of the University of Berne, Switzerland.

Tanks. Four tanks (200 1) supplied with dechlorinated tap water were divided into 2 equal compartments by a mesh. The water temperature was $10.5 \pm$ $0.5^{\circ} \mathrm{C}$.

Virus. A VHS virus isolate (second passage in BF-2 cells), serologically similar to the reference strain F1 and with proven high pathogenicity in rainbow trout, was used.

Experimental infection. Three groups of 50 fish each were infected by bathing in concentrations of $10^{2}$ (Group I), $10^{3.7}$ (Group II), and $10^{5}$ (Group III) TCID 50 VHS virus $\mathrm{ml}^{-1}$ of water for $60 \mathrm{~min}$ at $10^{\circ} \mathrm{C}\left(\mathrm{TCID}_{50}=\right.$ tissue infective dose $50 \%$ ). Each group was placed in 1 of 3 tanks, each divided into 2 compartments. One compartment was used for registration of mortality, and the other compartment for sampling of tissue when necessary, i.e. if there were no dead fish available at the time of tissue sampling (see below). Fifty control fish were exposed to an equal volume of virusfree phosphate-buffered saline (PBS), and handled as the infected fish.

Monitoring. Mortality in 1 compartment per tank was recorded daily. Dead trout from the same compartment or, if not available, dead or live fish from the other compartment were sampled at $0,2,3,8,24$, and $48 \mathrm{~h}$, and $4,6,7,8,10,13,14$, and $21 \mathrm{~d}$ post infection (p.i.) (2 fish on each occasion). Clinical symptoms, typically abnormal swimming behaviour, lethargy and darker-than-normal colour, were recorded and categorized as absent (0) or present (1).

Virus cultivation. Head kidney from each sampled fish was examined virologically by inoculation of homogenates (diluted 1:10 and 1:100 in PBS) onto BF-2 cells (Wolf et al. 1966). Inoculated cell cultures were incubated at $15^{\circ} \mathrm{C}$ for $7 \mathrm{~d}$, then subcultivated for another $7 \mathrm{~d}$. Cultures were examined daily for the presence of a distinct cytopathic effect (CPE). The serological examination was done by an indirect immunofluorescent antibody technique (IFAT) (Jørgensen $1974 \mathrm{~b}$ ), using rabbit antiserum against VHS virus (reference strain F1). 
Tissue sampling. Parallel tissue samples, from the same fish, of gills, brain, liver, posterior and head kidney, pyloric caeca including pancreas, and muscle were collected and fixed in phosphate buffered formalin ( $\mathrm{pH} 7.4$ ) for $24 \mathrm{~h}$. The samples were embedded in paraffin wax according to standard procedures (Meier \& Pfister 1981).

Immunohistochemical investigations. The immunohistochemical method was as described by Hsu et al. (1981), and as modified by Evensen (1993). Briefly, after deparaffinization, the sections were overlaid with a solution of $5 \%(\mathrm{w} / \mathrm{v})$ bovine serum albumin (BSA) in Tris-buffered saline (TBS, pH 7.4) for $20 \mathrm{~min}$, to block nonspecific binding sites. The solution was blotted off the slides and the polypeptide-specific polyclonal antibody against nucleoprotein ( $\mathrm{N}$-protein, see below) was incubated at a dilution of 1:500 for $30 \mathrm{~min}$ or 1:4000 for 18 to $20 \mathrm{~h}$. After washing for $5 \mathrm{~min}$ in TBS, the secondary antibody, biotinylated antirabbit immunoglobulin diluted 1:300 (Dakopatts, Glostrup, Denmark), was added and the mixture incubated for 30 min. After washing in TBS, avidin-biotin alkaline phosphatase (diluted 1:300, Dakopatts) was added and incubated for 30 to $45 \mathrm{~min}$ at room temperature. After washing, Fast Red ( $1 \mathrm{~g} \mathrm{l}^{-1}$; Sigma, St. Louis, MO, USA) and naphthol AS-MX-phosphate $\left(0.2 \mathrm{~g} \mathrm{l}^{-1}\right.$; Sigma) with $1 \mathrm{mM}$ levamisole (Sigma) as inhibitor in $0.1 \mathrm{M}$ TBS were added and allowed to develop for $20 \mathrm{~min}$. After washing in tap water, sections were counterstained with Mayer's haematoxylin and mounted in an aqueous mounting medium (Aquamount; BDH Laboratory Supplies). All incubations were performed at room temperature in a humidified chamber.

A preliminary study was performed on paraffinembedded, stored tissue specimens collected during outbreaks of VHS in Norway and France and from an experimental infection in Denmark. VHS virus was detected in all specimens previously recorded as virus positive.

Evaluation of positive or negative reaction in tissue sections from the experiment was performed without knowledge of the results from the virus cultivation.

Controls included use of nonimmune serum (normal rabbit serum) at the same dilution as the immune serum. Tissue sections from noninfected rainbow trout were also incubated with immune and nonimmune serum. In addition, we estimated end point dilution value (the highest dilution of the primary antibody that gives a positive reaction discernable from background) after 30 min incubation at room temperature (Petrusz 1983)

Production of polypeptide-specific polyclonal antibodies. Reference strain F1 of VHS virus (Jensen 1965) was cultivated in BF-2 cells (Wolf et al. 1966), and gradient-purified as described by de Kinkelin (1972).
After solubilization with sodium deoxycholate $(2 \%)$, Triton X-100 (2\%), and dithiothreitol $(10 \mathrm{mM})$ as described for pike fry rhabdovirus by Clerx \& Horzinek (1978), purified virus was allowed to react in cross-immunoelectrophoresis against an antiserum previously produced by immunizing rabbits with pelleted, non-gradient-purified F1 virus as described by Jørgensen (1974a). Immunoprecipitates were cut out of 18 gels, washed in 3 changes of PBS over $3 \mathrm{~d}$ at $4{ }^{\circ} \mathrm{C}$, homogenized by means of mortar and pestle, resuspended in PBS and then used as antigen for injection into rabbits. Each of 3 rabbits was given subcutaneous injections of antigen mixed with equal parts of Freund's incomplete adjuvant on Days 0, 15, 30 and 135, respectively, alternating with intraperitoneal injections of antigen without adjuvant on Days 45, 60 and 150 . The rabbits were bled $10 \mathrm{~d}$ after the last injection. Each rabbit received precipitates from 6 gels. When examined by Western blotting, the resulting antisera reacted only with the N-protein of VHS virus. Details concerning the cross-immunoelectrophoresis and the testing of the protein specificity of the antisera will be given elsewhere.

Comparison of techniques, and statistical evaluation. In immunohistochemical terms, sensitivity is expressed as the smallest amount of antigen revealed (Petrusz et al. 1980), and can only be evaluated in artificial antigen substrates in which known amounts of antigens are embedded (Avrameas \& Ternynck 1969, Brandtzaeg 1972). To compare the number of positives in immunohistochemistry with that of virus isolation, the results obtained were evaluated statistically using an exact binomial test (Sokal \& Rohlf 1981). The probability that the observed differences were due to chance alone was calculated using the binomial distribution. Differences were considered significant at $p \leq$ 0.05 . The agreement between the different tests was also measured, and a kappa value was calculated (Martin et al. 1987). Agreement was considered moderate, substantial and almost perfect at $0.4 \leq \kappa<0.6$, $0.6 \leq \kappa<0.8$, and $0.8 \leq \kappa \leq 1$, respectively.

\section{RESULTS}

The cumulative mortality in each group on Day 14 p.i. was 44,64 , and $96 \%$, for Groups I, II, and III, respectively (Fig. 1). The onset of mortality was on Day 8 for Groups I and II, and on Day 6 p.i. for Group III (Fig. 1). In the control fish, no mortality or presence of virus was observed.

In Group I $\left(10^{2} \mathrm{TCID}_{50} \mathrm{ml}^{-1}\right)$, the virus could be isolated by cultivation from Day 4 p.i. until the end of the experiment, whereas the presence of virus was demonstrated from Day 4 to 10 p.i. (only 1 fish on Day 10) by the 
Table 1. Oncorhynchus mykiss. Detection of VHS virus from rainbow trout by cultivation and immunohistochemistry at different times post infection for the different groups. Detection values are: no. of fish positive/no. of fish tested. Groups I, II and III infected were with $10^{2}, 10^{3.7}$ and $10^{5} \mathrm{TCID}_{50} \mathrm{ml}^{-1}$ water, respectively. Symptoms were evaluated as present (1) or absent $(0)$. ne: not examined

\begin{tabular}{|c|c|c|c|c|c|c|c|c|c|c|c|c|}
\hline & \multicolumn{11}{|c|}{ Days post infection: } & \multirow{2}{*}{$\begin{array}{l}\text { Total number } \\
\text { of fish positive }\end{array}$} \\
\hline & 0 & 1 & 2 & 4 & 6 & 7 & 8 & 10 & 13 & 14 & 21 & \\
\hline \multicolumn{13}{|l|}{ Group I } \\
\hline Virus isolation & $0 / 2$ & $0 / 2$ & $0 / 2$ & $2 / 2$ & $2 / 2$ & $2 / 2$ & $2 / 2$ & $2 / 2$ & $2 / 2$ & $1 / 2$ & $4 / 7$ & 17 \\
\hline Immunohistochemistry & $0 / 2$ & $0 / 2$ & $0 / 2$ & $2 / 2$ & $2 / 2$ & $2 / 2$ & $2 / 2$ & $1 / 2$ & $0 / 2$ & $0 / 2$ & $1 / 7$ & 10 \\
\hline Clinical symptoms & 0 & 0 & 0 & 0 & 1 & 1 & 1 & 1 & 1 & 0 & 1 & \\
\hline \multicolumn{13}{|l|}{ Group II } \\
\hline Virus isolation & $0 / 2$ & $0 / 2$ & $2 / 2$ & $2 / 2$ & $2 / 2$ & $2 / 2$ & $2 / 2$ & $2 / 2$ & $1 / 2$ & $2 / 2$ & $1 / 2$ & 16 \\
\hline Immunohistochemistry & $0 / 2$ & $0 / 2$ & $1 / 2$ & $2 / 2$ & $2 / 2$ & $2 / 2$ & $2 / 2$ & $1 / 2$ & $1 / 2$ & $0 / 2$ & $0 / 2$ & 11 \\
\hline Clinical symptoms & 0 & 0 & 0 & 0 & 1 & 1 & 0 & 1 & 1 & 1 & 1 & \\
\hline \multicolumn{13}{|l|}{ Group III } \\
\hline Virus isolation & $0 / 2$ & $0 / 2$ & $2 / 2$ & $2 / 2$ & $2 / 2$ & ne & $2 / 2$ & $2 / 2$ & ne & $2 / 2$ & ne & 12 \\
\hline Immunohistochemistry & $0 / 2$ & $0 / 2$ & $0 / 2$ & $2 / 2$ & $2 / 2$ & ne & $2 / 2$ & $2 / 2$ & ne & $2 / 2$ & ne & 10 \\
\hline Clinical symptoms & 0 & 0 & 0 & 1 & 1 & ne & 0 & 1 & ne & 1 & ne & \\
\hline
\end{tabular}

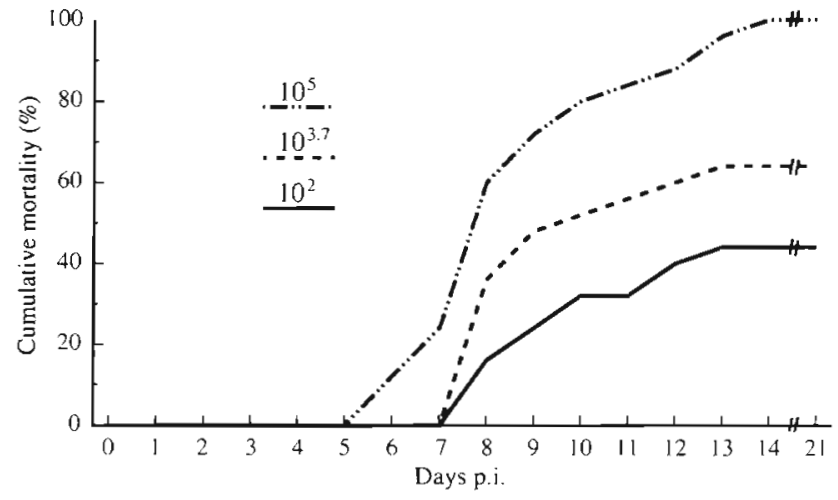

Fig. 1 Oncorhynchus mykiss. Cumulative mortality in the 3 groups of rainbow trout infected with different doses of VHS virus: $10^{2}, 10^{3.7}$, and $10^{5} \mathrm{TCID}_{50} \mathrm{ml}^{-1}$

immunohistochemical method (Table 1). At later stages (Day 21), virus antigens were demonstrated in tissue sections from 1 fish (kidney) by immunohistochemistry. In Group II ( $\left.10^{37} \mathrm{TCID}_{50} \mathrm{ml}^{-1}\right)$, virus was revealed by isolation from $48 \mathrm{~h}$ p.i. until the end of the experiment, and from 48 h p.i. (1 of 2 fish) to Day 13 p.i. (1 of 2 fish) by the immunohistochemical method (Table 1 ).

In Group III $\left(10^{5} \mathrm{TCID}_{50} \mathrm{ml}^{-1}\right)$, virus could be isolated from 48 h p.i. to Day 14 p.i. By Day 21, all the fish had died. Virus was demonstrated in situ from Day 4 until Day 14 p.i. (Table 1).

By immunohistochemistry, virus was detected as early as $48 \mathrm{~h}$ p.i. interstitially in the head kidney, and at $4 \mathrm{~d}$ p.i. in endothelial cells lining venules and sinusoids in the anterior and posterior kidney (Fig. 2). Interstitial macrophages and melanomacrophages closely apposed to sinusoids/endothelial cells were also positively stained (Fig. 3). Single cells showed morphological signs of degeneration, revealed as fragmentation of the pigment granules of melanomacrophages (Fig. 4). In Group III, there was a more intense staining of endothelial cells in small venules and sinusoids in the kidney compared to the 2 other groups at this time; these cells also showed signs of degeneration, initially revealed as indistinct cell borders. At 7 d p.i., virus was detected in association with necrosis in accumulations of melanomacrophages, so-called melanomacrophage

Figs. 2 to 7. Oncorhynchus mykiss. Tissue sections from VHSV-infected fish stained using an avidin-biotin alkaline phosphatase method with Mayer's haematoxylin counterstain. Fig. 2. Kidney, 4 d post infection (p.i.), Group Il. VHS virus is demonstrated in endothelial cells lining a venule and revealed as red, cytoplasmic staining (black arrow). There are no morphological signs of cell degeneration. Positive staining is also revealed in haematopoietic cells (white arrows). $\times 530$. Fig. 3. Kidney, 4 d p.i., Group I. Positive staining for VHS virus is demonstrated in macrophages and melanomacrophages located interstitially. Note positive staining also in endothelial cell (arrow). $\times 1330$. Fig. 4 . Kidney, $4 \mathrm{~d}$ p.i., Group III. Positive cytoplasmic staining is seen in macrophages and melanomacrophages (white arrows). Note the fragmentation of melanomacrophages with extracellular location of granules (black arrow). Also observe positive staining in remnants of necrotic cells (star) $\times 1330$. Fig. 5. Kidney, 7 d p.i., Group III. Focal necrosis with positive staining for VHS virus (arrows), especially in cells located in the periphery of the necrotic area. $\times 840$. Fig. 6 . Liver, $4 \mathrm{~d}$ p.i., Group III. One hepatocyte with strong cytoplasmic staining for VHS virus, without concomitant morphological signs of degeneration Endothelial cells are negative. $\times 530$. Fig. 7 . Exocrine pancreas, $6 \mathrm{~d}$ p.i., Group II Positive staining is revealed in degenerate exocrine pancreatic cells. Note positive staining in pancreatic cell without degenerative changes (arrow). $\times 530$ 

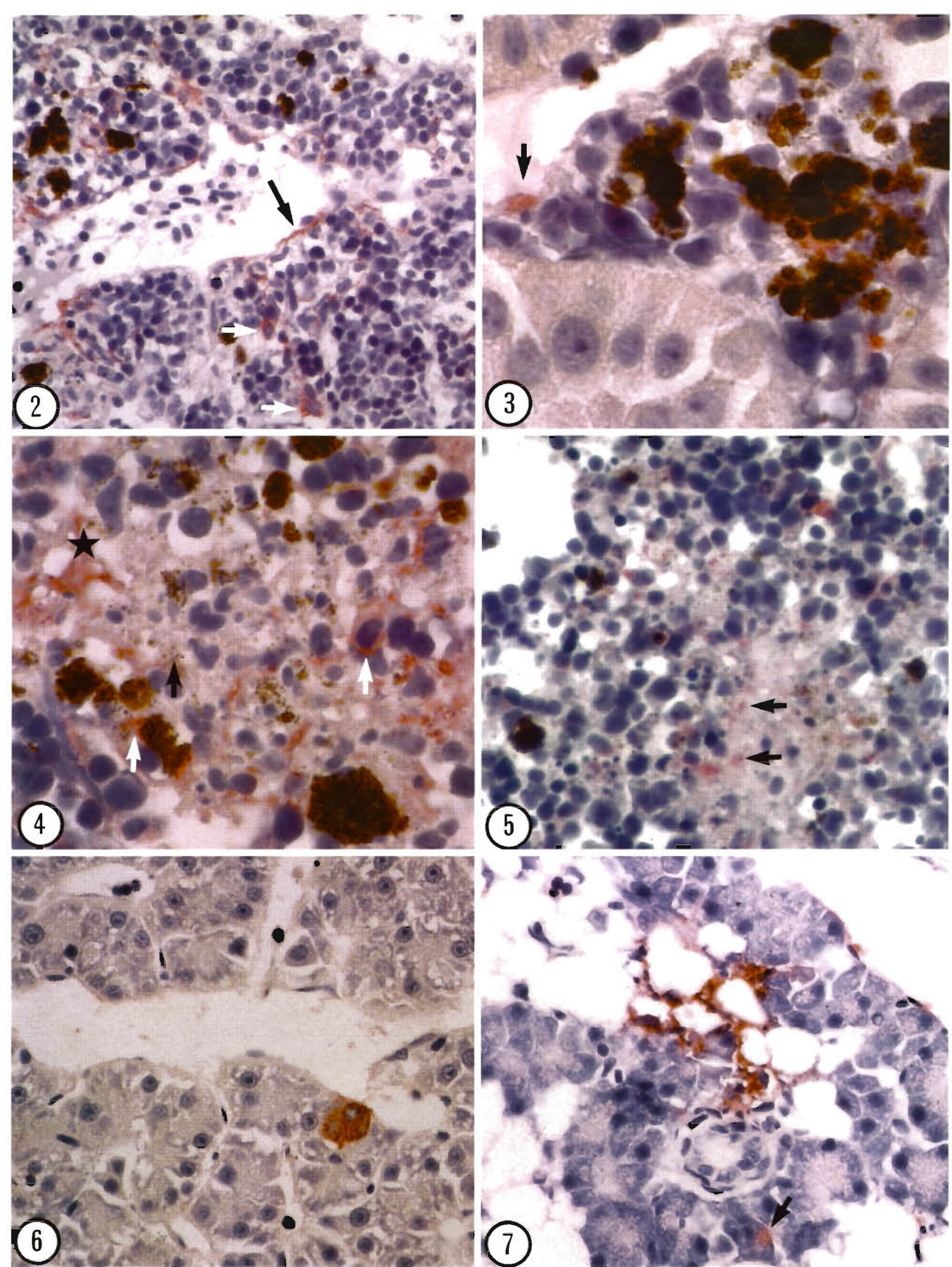

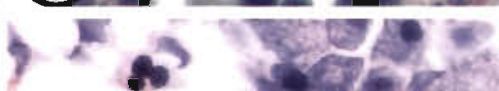

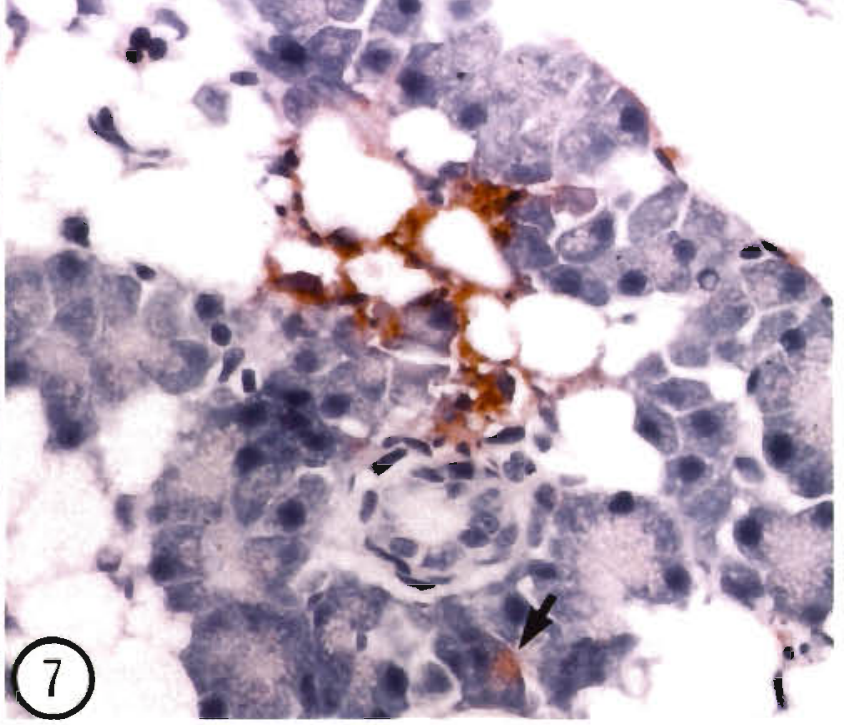


centres, and focal necroses were also present at this time (Fig. 5).

At 4 d p.i., virus was demonstrated in hepatocytes in all groups, also with concomitant degeneration and necrosis of single cells (Fig. 6). Virus was not detected in endothelial cells in the liver (Fig. 6). At later stages, 7 d p.i., focal necroses were present (not shown).

Virus was detected in exocrine pancreatic cells in all groups 6 d p.i., usually with necrosis of single exocrine cells (Fig. 7). Moderate infiltration of inflammatory cells was occasionally seen in areas of degeneration. Virus was also detected in pillar cells of the secondary lamellae of the gills (Groups I and III, $7 \mathrm{~d}$ p.i.), and sometimes in the musculature (not shown). At late stages (13 and $14 \mathrm{~d}$ p.i.), virus was still detectable in interstitial cells in the head kidney and in parenchymal liver cells. Virus was not detected in brain sections at any stage of the disease.

Overall, virus was detected by immunohistochemistry in 31 fish out of the 45 fish found positive by virus isolation (Table 1). In 30 of these fish, virus was detected in the head kidney. In comparison, virus was demonstrated in the liver of 17 fish and in the exocrine pancreas of $12 \mathrm{fish}$.

Out of the 65 fish examined for presence of virus by cultivation and immunohistochemistry, 14 samples were positive by cultivation although negative by immunohistochemistry (Table 1). The binomial test showed a significant difference between the 2 methods when evaluated for all groups $(p=0.000061)$, i.e. cultivation was significantly more sensitive than immunohistochemistry for detection of VHS virus.

Comparison of the methods separately for Groups I, II, and III shows that virus cultivation was significantly more sensitive than immunohistochemistry for Groups I and II, but not for Group III ( $p=0.25)$. When comparing the results obtained during the exponential phase of the cumulative death curve (Days 6-7 to 14) p-values of 0.0625 were obtained for Groups I and II, and there was a perfect agreement between the 2 methods for Group III $(\kappa=1)$.

The $\kappa$-values, ranging from 0.455 to 0.714 , reflect a moderate to substantial level of agreement between the 2 methods.

\section{DISCUSSION}

The present study demonstrated the in situ detection of VHS virus in formalin-fixed, paraffin-embedded tissue specimens by polypeptide-specific polyclonal antibodies and an avidin-biotin alkaline phosphatase method. Companson of virus isolation and immunohistochemistry showed virus cultivation to be significantly more sensitive than immunohisto- chemistry; however, the difference was not significant at high infection doses $\left(10^{5} \mathrm{TCID}_{50} \mathrm{ml}^{-1}\right)$ or during the exponential phase of the death curve. In the course of the experimental infection, virus was first demonstrated in situ in the kidney tissue in haematopoietic cells, in endothelial cells lining the venules and sinusoids, and subsequently, in the parenchymal liver cells, exocrine pancreatic cells, and gills. Virus antigens were revealed in situ simultaneously with the demonstration of cell degeneration and necrosis in different organs.

The few reports published comparing the use of in situ methods and virus cultivation for identification of VHS virus included frozen specimens for in situ detection (Jørgensen \& Meyling 1972, Ortega et al. 1992). Kruse \& Neukirch (1989) have previously compared detection of virus in formalin-fixed, paraffin-embedded tissue specimens with detection by virus cultivation; however, they did not estimate the sensitivity of the 2 methods used. In the present study, lack of a significant difference between the 2 methods at a high infection dose (Group III) and during the acute phase of the disease (exponential phase of the cumulative death curve) was intriguing, and these findings are in agreement with those reported earlier using the immunofluorescence technique (Jørgensen \& Meyling 1972). However, the presence of defective virus particles could interfere with the sensitivity of cultivation at high concentrations of virus. On the other hand, this suggests that immunohistochemistry may be useful as an adjunct for diagnosis of VHS during acute outbreaks of the disease, especially since defective particles supposedly can be detected in situ by immunohistochemistry. In contrast to immunofluorescence, immunoenzyme methods allow the simultaneous evaluation of pathological changes and in situ demonstration of virus. This duality of the immunoenzyme methods makes them superior to immunofluorescence and significantly assists in diagnosis. Nevertheless, at low infection doses (as reported herein) and during the chronic phase of infection (Jørgensen \& Meyling 1972), virus cultivation is significantly more sensitive than immunohistochemistry, and is the method of choice for diagnosis of VHS virus infection. In general, immunohistochemistry can aid in diagnosis, but a negative result should be interpreted with caution (Petrusz 1983)

Tissue preparation is a critical step in immunohistochemistry, especially the fixation method (Brandtzaeg 1982). It has been shown that formalin fixation reduces the sensitivity of immunohistochemical techniques compared to precipitating fixatives, when using immune sera or monoclonal antibodies against protein epitopes (Brandtzaeg \& Rognum 1984, Valnes et al. 1984). The differences in detection sensitivity, ex- 
pressed as the smallest amount of antigen revealed (Petrusz et al. 1980), may range from 3- to 8-fold between ethanol and formalin fixation when evaluated in artificial antigen media (Brandtzaeg \& Rognum 1984, Valnes et al. 1984, Evensen et al. 1994); the adverse effects induced by fixation, especially by the aldehyde-containing fixatives, include the masking of tissue antigens with loss of antigenicity. The most recent previous report on in situ demonstration of VHS virus describes a higher sensitivity of immunofluorescence methods compared to virus isolation when physical fixation and frozen sections are used (Ortega et al. 1992). In this light, further studies should be performed to evaluate and improve the sensitivity of the immunohistochemical methods for detection of VHS virus, including the use of different precipitating and crosslinking fixatives.

The prime target organs in VHS virus infection are the kidney and the liver, this conclusion being based on the extent of tissue degeneration and necrosis in these organs (de Kinkelin et al. 1979, Wolf 1988). Previous studies (Meier \& Pfister 1981, Wizigmann \& Hoffmann 1982) reported endothelial cell degeneration at early stages of infection, preceding parenchymal degeneration and necrosis. This succession was not confirmed in the present study, but evaluation of endothelial cell degeneration might be difficult at the light microscopic level. In addition, the exact nature of the target cells is not known (de Kinkelin et al. 1979), but, as shown in this study, there seems to be an intense replication of virus in many interstitial cells, including macrophages and melanomacrophages early during the infection, with consequent cell degeneration and necrosis. Hepatocytes are also affected during a VHS virus infection, and degeneration in single hepatocytes and simultaneous presence of virus were also demonstrated at an early stage (4 d p.i.). However, virus was not detected in endothelial cells lining the sinusoids in the liver, in contrast to the observations made for endothelial cells lining the kidney venules and sinusoids. The significance of these findings is not easily interpreted. At $6 \mathrm{~d}$ p.i., virus was also detected in exocrine pancreatic cells together with concomitant cell degeneration and necrosis. Virus was not demonstrated in the gills at early stages of infection, being first detected at $7 \mathrm{~d}$ p.i. in pillar cells in the secondary lamellae. The latter observation is in agreement with the report of Wizigmann \& Hoffmann (1982), but discordant with other reports (Ahne 1978, Neukirch 1984). Neukirch (1984) isolated virus from gill samples during the initial phase of a waterborne experimental infection induced by an infection titer and exposure time identical to those reported here. The general opinion is that the gills are the prime portal of entry when virus is transmitted in water (Wolf 1988), although a recent report has focused on the epidermis and epidermal tissues as a possible site for entry and early virus replication (Yamamoto et al. 1992). The findings reported herein concur with the observations reported by others with regard to the sequential in situ detection of virus during an experimental infection, but there is still need for better characterization of the prime target cells in VHS virus infections. Immunohistochemical techniques are of special value in this context.

Virus was not detected in situ in brain tissue at any time during the experiment. These findings are in contrast to those reported by others (Kruse \& Neukirch 1989) who found that virus could be detected in situ in brain tissue 5 d after infection by use of an immunoperoxidase technique. The contrasting observations are not easily explained but different experimental designs, the use of different virus strains and different antisera may cause variation between experiments. Furthermore, tissue preparation, as discussed earlier, will obviously influence the results obtained using immunohistochemical methods. The observations referred to in the literature are also inconsistent with regard to in situ detection of VHS virus in the nervous tissue of the brain. A previous study demonstrated virus in the endothelial cells in the brain, but not in the nervous tissue (Wizigmann \& Hoffmann 1982), while others have reisolated VHS virus from the brain at a stage of disease where the virus was not present in other organs (Neukirch 1986). The latter findings are in agreement with the observation that virus can be reisolated from brain tissue during the chronic course of a natural infection (authors' pers. obs.). Obviously, there is a need for further studies to identify the target cells in brain tissue of VHS virus infected fish.

When comparing 2 methods, one may ascertain whether one test gives more positive responses than the other (Martin 1977), and also assess the extent to which the different methods classify the same individuals/samples into the same category (test positive or test negative). This means it is possible to measure agreement beyond the level associated with pure chance, expressed as the K-value (Martin 1977). Furthermore, a high $\kappa$-value indicates that the tests measure what they purport to measure, and a $\kappa$ of 0.4 to 0.5 indicates a moderate level of agreement (Martin et al. 1987). On this basis, the present study demonstrated moderate to substantial agreement between immunohistochemistry and virus isolation, and indicated that both methods measure what they intend to measure. However, virus isolation is significantly more sensitive than immunohistochemistry, and again, should be the method of choice for detection of VHS virus. 
Acknowledgements. We gratefully acknowledge the competent technical assistance of $\mathrm{N}$ s Randi Terland, and the proficient statistical evaluations provided by Dr Eystein Skjerve. We also thank Dr P. de Kinkelin for providıng paraffin-embedded specimens from verified outbreaks of VHS in France.

\section{LITERATURE CITED}

Ahne, W. (1978). Uptake and multiplication of spring viraemia of carp virus in carp. Cyprinus carpio L. J. Fish Dis. 1: $265-268$

Ahne, W., Negele, R. D., Ollenschlager, B. (1976). Vergleichende Infektionsversuche mit Egtved-viren (Stamm F1) bei Regenbogenforellen (Salmo gairdneri) und Goldforellen (Salmo aguabonita). Berl. Münch. tierärtzl. Wochenschr. 89: 161-164

Ahne, W. Thomsen, 1. (1985). Occurrence of VHS virus in wild white fish (Coregonus sp.). Zentralbl. Veterinärmed. (B) $32: 73-75$

Avrameas, S., Ternynck, T. (1969). The crosslinking of proteins with glutaraldehyde and its use for preparation of immunoadsorbents. Immunochemistry 6: 53-66

Brandtzaeg. P. (1972). Evaluation of immunofluorescence with artificial sections of selected antigenicity. Immunology $22: 177-183$

Brandtzaeg, P. (1982). Tissue preparation methods for immunohistochemistry. In: Bullock, G. R., Petrusz, P. (eds.) Techniques in immunocytochemistry. Academic Press, London, p. 2-75

Brandtzaeg, P., Rognum, T. O. (1984). Evaluation of nine different fixatives. 2. Preservation of $\operatorname{IgG}, \operatorname{Ig} A$ and secretory component in an artificial immunohistochemical test substrate. Histochemistry 81. 213-219

Castric, J, de Kinkelin, P. (1984). Experimental study of the susceptibility of two marine fish species, sea bass (Dicentrarchus labrax) and turbot (Scophthalmus maximus), to viral hemorrhagic septicaemia. Aquaculture 41: 203-212

Clerx, J. P. M., Horzinek, M. C. (1978). Comparative protein analysis of non-salmonid fish rhabdoviruses. J. gen. Virol. 40: $287-295$

de Kinkelin, P. (1972). Le virus d'egtved. II. Purification. Ann. Rech. vét. 3 (2): 199-208

de Kinkelin, P., Castric, J. (1982). An experimental study of the susceptibility of Atlantic salmon fry, Salmo salar L., to viral haemorrhagic septicaemia. J. Fish Dis, 5: 57-65

de Kinkelin, P., Chilmonczyk, S., Dorson, M., Le Berre, M., Baudouy, A.-M. (1979). Some pathogenic facets of rhabdoviral infection of salmonid fish. In: Bachmann, P. A. (ed.) Symposia on microbiology: mechanisms of viral pathogenesis and virulence. WHO Collaborating Centre for Collection and Education of Data on Comparitive Virology, Munich, p. 357-375

de Kinkelin, P., Le Berre, M. (1977). Isolement d'un rhabdovirus pathogene de la truite fario (Salmo trutta). C.r. Acad. Sci. Paris 284: 101-104

Evensen, Ø. (1993). An immunohistochemical study on the cytogenetic orıgin of pulmonary multinucleate giant cells in porcine dermatosis vegetans. Vet. Pathol. 31: 162-1.70

Evensen, Ø., Dale, O. B., Nilsen, A. (1994). Immunohistochemical identification of Renibacterium salmoninarum by monoclonal antibodies in paraffin-embedded tissues of Atlantic salmon (Salmo salar L.) using paired immunoenzyme and paired immunofluorescence techniques. J. vet. diagn. Invest. 6: 48-55

Faisal, M., Ahne, W. (1980). Use of immunoperoxidase technique for detection of fish virus antigens. In: Ahne, W (ed.) Fish diseases. Third COPRAQ session. Springer-
Verlag, Berlin, p. 186-192

Hsu, S. M., Raine, L., Fanger, H. (1981). Use of ān avidinbiotin-peroxidase complex (ABC) in immunoperoxidase techniques: a comparison between $A B C$ and unlabelled antibody (PA.P) procedures. J. Histochem. Cytochem. 29 $577-580$

Jensen, M. H. (1965). Research on the virus of Egtved disease. Ann. N.Y. Acad. Sci. 126: 422-426

Jensen, N. J., Bloch, B., Larsen, J. L. (1979). The ulcus syndrome in cod (Gadus morhua). III. A preliminary virological report. Nord. Vet.-Med. 31:436-442

Jørgensen, P. E. V. (1974a). A study of viral diseases in Danish rainbow trout. Their diagnosis and control. Ph.D. thesis, Royal Velerinary and Agricultural University, Copenhagen

Jorgensen, P. E. V. (1974b). Indirect fluorescent antibody techniques for demonstration of trout viruses and corresponding antibody. Acta vet. scand. 15: 198-205

Jorgensen, P. E. V., Meyling, A. (1972). Egtved virus: demonstration of virus antigen by the fluorescent antibody technique in tissues of rainbow trout affected by viral haemorrhagic septicaemia and in cell cultures infected with Egtved virus. Arch. Virusforsch. 36: 115-122

Jørgensen, P. E. V., Olesen, N. J. (1987). Cod ulcus syndrome rhabdovirus is indistinguishable from Egtved (VHS) virus Bull. Eur. Ass. Fish Pathol. 7: 73-74

Kruse, P., Neukirch, M. (1989). The significance of rainbow trout brain and excretory kidney for the propagation of viral haemorrhagic septicaemia (VHS) virus. In: Ahne, W. Kurstak, E. (eds.) Viruses of lower vertebrates. SpringerVerlag, Berlin, p. $367-378$

Martin, S. W. (1977). The evaluation of tests. Can. J. comp Med $41 \quad 19-25$

Martin, S. W., Meek, A. H., Willeberg, P. (1987). Veterinary epidemiology. Principles and methods. lowa State University Press, Ames, p. 121-148

Meier, W., Ahne, W., Jørgensen, P. E. V (1986). Fish viruses: viral haemorrhagic septicaemia in white fish (Coregonus sp.). J. appl. Ichthyol. 4: 181-186

Meier, W., Jorgensen, P. E. V. (1979). Egtved virus: characteristics of a virus strain isolated from pike fry (Esox lucius L.). Nord. Vet.-Med. 31: 484-485

Meier, W., Pfister, K. (1981). Viral hemorrhagic septicemia (VHS) in pike (Esox lucius L.). Clinical, macroscopic, histological and electron-microscopical findings; direct visualization of Egtved virus. Schweiz. Arch. Tierheilkd. 123: $37-49$

Neukirch, M. (1984). An experimental study of the entry and multiplication of viral haemorrhagic septicaemia virus in rainbow trout, Salmo gairdneri Richardson, after waterborne infection. J. Fish Dis. 7: 231-234

Neukırch, M. (1986). Demonstration of persistent viral haemorrhagic septicaemia (VHS) virus in rainbow trout after experimental waterborne infection. J. vet. Med. (B) 33 $471-476$

Ortega, C., Milani, J. L., Muzquiz, J. L., Alonso, J. L., Simon, M. C., Garcia, O., Girones, O., Graselli, A. (1992). Comparative study of the fluorescent antibody technique and cell culture isolation in the diagnosis of VHS. Bull. Eur. Ass. Fish Pathol. 12: 191-193

Oshima, K. H., Higman, K. H., Arakawa, C. K., de Kinkelin, P., Jørgensen, P. E. V., Meyers, T R., Winton, J. R. (1993). Genetic comparison of viral hemorrhagic septicemia virus isolates from North America and Europe. Dis. aquat. Org. 17: $73-80$

Petrusz, P. (1983). Essential requirements for the validity of immunocytochemical staining procedures. J. Histochem. Cytochem. 31. 177-179 
Petrusz, P., Ordronneau, O., Finley, J. C.W. (1980). Criteria of reliability for light microscopic immunocytochemical staining. Histochem. J. 12: 333-348

Rasmussen, C. J. (1965). A biological study of the VHS virus (INUL). Ann. N.Y Acad. Sci. 126: 427-460

Sanz, F., Coll, J. M. (1992). Detection of viral haemorrhagic septicaemia virus by indirect immunoperoxidase with selected anti-nucleoprotein monoclonal antıbody. Bull. Eur. Ass. Fish Pathol. 12: 116-119

Sokal, R. R., Rohlf, F. J. (1981). Biometry, 2nd edn. W. H. Freeman and Company, New York, p. 774

Valnes, K., Brandtzaeg, P., Rognum, T O. (1984). Sensitivity and efficiency of four immunohıstochemical methods as defined by staining of artificial sections. Histochemistry 81: $313-319$

Wizigmann, G., Baath, C., Hoffmann, R. (1980). Isolıerung des Virus der viralen hämorrhagischen Septikämie (VHS) aus

Responsible Subject Editor: F. M. Hetrick, College Park, Maryland, USA
Regenbogenforellen-, Hecht- und Äschenbrut. Zentralbl. Veterinärmed. (B) 27-79-81

Wizigmann, G., Hoffmann, R. (1982). Vergleichende lichtmikroskopische und immunhistologische Untersuchungen bel der viralen hämorrhagıschen Septikamie (VHS) der Regenbogenforelle. Zentralbl. Veternärmed. (B) 29 : $782-788$

Wolf, K. (1988). Viral hemorrhagic septicemia. In: Fish viruses and fish viral diseases. Cornell University Press, Ithaca, NY, p. 217-249

Wolt, K., Gravell, M., Malsberger, R. G. (1966). Lymphocystis virus: isolation and propagation in centrarchid fish cell lunes. Science 151: 1004-1005

Yamamoto, T., Batts, W. N., Winton, J. R. (1992). In vitro infection of salmonid epidermal tissues by infectious hematopoietic necrosis virus and viral hemorrhagic septicemia virus. J. aquat. Anim. Health 4: 231-239

Manuscript first received: February 16, 1994 Revised version accepted: June 16, 1994 